\title{
Challenges of Applying On-Site Photovoltaic System At Environmetally Friendly Buildings In Indonesia
}

\author{
Esterlita Hisamatsu ${ }^{1}$, Annisa ${ }^{1}$, Siswanti Zuraida ${ }^{1}$ \\ Teknik Sipiln, Fakultas Teknik dan Desain, Institut Teknologi Sains Bandung, Cikarang Pusat, Indonesia \\ E-mail: hisamatsuesterlita@gmail.com \\ annisa@itsb.ac.id \\ siswanti.zuraida@itsb.ac.id
}

Informasi naskah:

Diterima

20 Juli 2021

Direvisi

01 Agustus 2021

Disetujui terbit

30 Agustus 2021

Diterbitkan

9 September 2021

\begin{abstract}
Seventh goal of the "Sustainable Development Goals (SDGs)" is clean and affordable energy to increase the proportion of renewable energy. However, power plants in Indonesia are still dominated by nonrenewable energy. Therefore, it is necessary to have renewable energy technologies such as photovoltaic that can be installed on-site in buildings as an alternative clean electricity supplier. Even though Indonesia has abundant sun energy, domestic photovoltaic development is relatively slow. This research aims to identify obstacles to the application of photovoltaic as an on-site electrical system in Indonesia by spreading questionnaire to experts and users. Each question in the questionnaire is related to the understanding of the three pillars of sustainability (environment, social, and economic) related to on-site photovoltaic. The results of the data will be tested using the one sample t-test method to identify the environmental barriers, social barriers, and economic barriers. The results of this study indicate that the constraints of photovoltaic as an on-site power plant are generally dominated by social and economic barriers. Meanwhile, environmental barriers are recessive.
\end{abstract}

Keywords: Sustainable Development, On-Site Photovoltaic 


\section{INTRODUCTION}

Indonesia and 192 other countries have officially ratified the "Sustainable Development Goals (SDGs)" through the general assembly of the United Nations (UN) in New York on September 25, 2015. The SDGs contains of 17 Global Goal and 169 Global Targets. The seventh goal of the SDGs is clean and affordable energy in order to increase the proportion of renewable energy in global energy use ${ }^{[1]}$. The application of clean and affordable energy aims to supply the public's energy needs while meeting the environmental sustainability, social sustainability, and economic sustainability.

According to "Global Status Report for Buildings and Construction", the United Nations with the International Energy Agency concluded that clean energy should be developed in the building sector, especially at the building operational cycle. It is known that buildings have become the largest contributor to global emissions, amounting to $39 \%$ consisting of $28 \%$ building operations and $11 \%$ building materials and construction ${ }^{[2]}$. Seeing that central power plants in Indonesia are still dominated by non-renewable energy, it is necessary to have energy technology installed directly on buildings as an alternative clean electricity supplier ${ }^{[3]}$. Therefore, photovoltaic solar panel is widely used as an alternative to clean electricity technology in global buildings because its operations does not produce emissions ${ }^{[4]}$.

Indonesia has great photovoltaic potential. Indonesia's geographical location is on the equator so that solar radiation in Indonesia tends to be more constant throughout the year. Even so, the development of photovoltaic in Indonesia is still relatively slow. On September 13, 2017, the National Movement for a Million Solar Roofs (GNSSA) was initiated by the government to support the SDGs by increasing the use of clean electricity from photovoltaics. GNSSA targeting 1 Gigawatt (1000 Megawatt) capacity of photovoltaic installation before 2020. However, the photovoltaic electricity capacity installed in 2019 shows a significant difference from the target. According to IESR (2019), the installed photovoltaic electricity capacity only reached $1.66 \%$ of the target, which is 16.66 Megawatts ${ }^{[5]}$.

The failure to achieve the GNSSA's target indicates that there are obstacles in the growth of on-site photovoltaics in Indonesia. This research was conducted with the aim of knowing whether there are environmental, social, and economic barriers in the development of on-site photovoltaic in Indonesia. Overall, this study may help the reader to identify which barriers is dominant than other.

\section{METHODS}

\subsection{Methodological Approach}

This study uses descriptive method with a quantitative approach. Descriptive method is used with the aim of explaining a situation by using variable indicators. Each variable indicators were searched through study literature. Four source of secondary data was simplified into Tables ${ }^{[6]}\left[{ }^{[7]}\left[{ }^{[8]}{ }^{[9]}\right.\right.$. As it is shown in the tables, the variable indicators tend to 
be broad and difficult to observe. Therefore, an online questionnaire is designed to allow local experts and users to assess the presence of obstacles in each variable indicator.

\subsection{Variable Indicators}

\section{Table 1. Environmental barrier variables}

\begin{tabular}{|c|c|c|}
\hline Variable & Sub Variable & Description \\
\hline $\begin{array}{l}\text { Impact of Photovoltaic manufactur to the } \\
\text { environment }\end{array}$ & compount that are harmfull to the environment & $\begin{array}{l}\text { Indium } \\
\text { Galium } \\
\text { Selunium } \\
\text { Kadmium } \\
\text { Terulium } \\
\text { Lead }\end{array}$ \\
\hline
\end{tabular}

Table 2. Social barrier variables

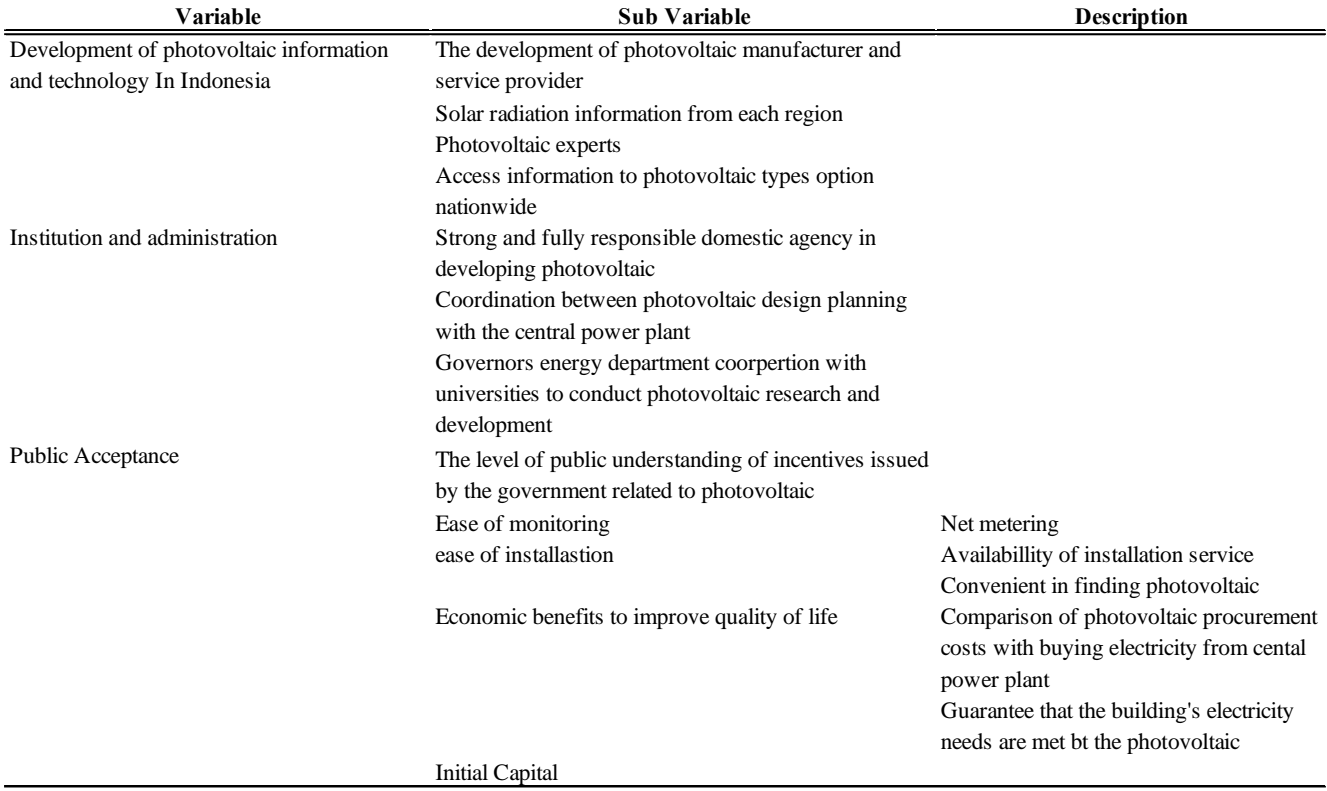

Table 3. Social barrier variables

\begin{tabular}{lll}
\multicolumn{1}{c}{ Variable } & \multicolumn{1}{c}{ Sub Variable } & \multicolumn{1}{c}{ Description } \\
\hline \hline state's economic condition & $\begin{array}{l}\text { State's financial crisis causes difficulty to newly } \\
\text { established photovoltaic companies to develop } \\
\text { Photovoltaic selling price on market }\end{array}$ & $\begin{array}{l}\text { Photovoltaic process cost } \\
\text { Cost of semiconductor as photovoltaic's } \\
\text { material }\end{array}$ \\
& $\begin{array}{l}\text { Photovoltaic efficiency in producing electrical energy } \\
\text { National market price decline }\end{array}$ & \\
Financial institution's trust in the photovoltaic & \\
industry & &
\end{tabular}




\subsection{Data Analysis Method}

\subsubsection{Reliability and Validity Method}

Respondent answers are limited to a Likert scale (from 1-5) so that the results of the collected data are ordinal number and non-parametric. Therefore, Cronbach's alpha and spearman method is used to test ordinal and non-parametric data. Cronbach's alpha was used to test the reliability of the research instrument, while Spearman method is used to test the validity of the research instrument. The result shows a total of 25 reliable and valid data which then analyzed using one sample Wilcoxon method.

\subsubsection{One Sample Wilcoxon}

The one-sample Wilcoxon test was conducted with the aim of proving statistically the presence of obstacles related to the question items by hypothesizing the population median. The population median is hypothesized based on the condition described by the sample data. Each answer given by respondent are rated to number from 1 to 5 . Based on the rating scale, higher number indicate that the respondent agreed to the presence of obstacle; lower the number indicate there are no obstacle; while number 3 indicate to neutral answer. Therefore, If the population median is above 3 , it is concluded that there are obstacles in the actual condition.

Table 5. One Sample Wilcoxon Test Result

\begin{tabular}{|c|c|c|c|c|c|}
\hline Factor & Code & Significance & \begin{tabular}{|c|} 
Population \\
Median
\end{tabular} & $\begin{array}{c}\text { Accepted } \\
\text { Hipothesis }\end{array}$ & Conclusion \\
\hline \multirow{7}{*}{$\begin{array}{c}\text { Enviromental } \\
\text { Issue }\end{array}$} & L1 & 0,808 & 2 & Ho & no obstacle \\
\hline & L2 & 0,763 & 2 & Ho & no obstacle \\
\hline & L3 & 0,21 & 2,5 & Ho & no obstacle \\
\hline & L5 & 0,169 & 4 & Ho & presence of obstacle \\
\hline & L8 & 0,109 & 2 & Ho & no obstacle \\
\hline & L12 & 0,138 & 2 & Ho & no obstacle \\
\hline & L13 & 0,758 & 2,5 & Ho & no obstacle \\
\hline \multirow{10}{*}{ Social Issue } & $\mathrm{S} 1$ & 0,101 & 4 & Ho & presence of obstacle \\
\hline & S3 & 0,058 & 2,5 & Ho & no obstacle \\
\hline & S5 & 0,576 & 3,5 & Ho & presence of obstacle \\
\hline & S6 & 0,54 & 2,5 & Ho & no obstacle \\
\hline & S7 & 0,213 & 3,2 & Ho & presence of obstacle \\
\hline & S8 & 0,864 & 3,9 & Ho & presence of obstacle \\
\hline & S9 & 0,425 & 3,9 & Ho & presence of obstacle \\
\hline & $\mathrm{S} 10$ & 0,218 & 2,6 & Ho & no obstacle \\
\hline & $\mathrm{S} 12$ & 0,085 & 3,9 & Ho & presence of obstacle \\
\hline & S13 & 0,383 & 3,9 & Ho & presence of obstacle \\
\hline \multirow{8}{*}{$\begin{array}{l}\text { Economic } \\
\text { Issue }\end{array}$} & $\mathrm{E} 4$ & 0,124 & 2,5 & Ho & no obstacle \\
\hline & E5 & 0,675 & 4 & Ho & presence of obstacle \\
\hline & E6 & 0,928 & 4 & Ho & presence of obstacle \\
\hline & E7 & 0,156 & 3,9 & Ho & presence of obstacle \\
\hline & E9 & 0,502 & 3,5 & Ho & presence of obstacle \\
\hline & E10 & 0,125 & 3,9 & Ho & presence of obstacle \\
\hline & E12 & 0,125 & 3,9 & Ho & presence of obstacle \\
\hline & E13 & 0,808 & 4 & Ho & presence of obstacle \\
\hline
\end{tabular}

\section{RESULT AND DISCUSSION}

\subsection{Photovoltaic Information and Technology Development}

It is statistically approved that the development of photovoltaic information and technology in Indonesia is slow. IESR believes that the development of solar power plants 
in Indonesia is relatively slow compared to other Asian countries ${ }^{[10]}$. The application of rooftop solar panel in Indonesia itself is still very limited. Indonesian people do not have equal access to information and variations of rooftop solar technology. Information related to rooftop solar, both technology variations, to policies and regulations, and technical information, is still limited to the upper middle class.

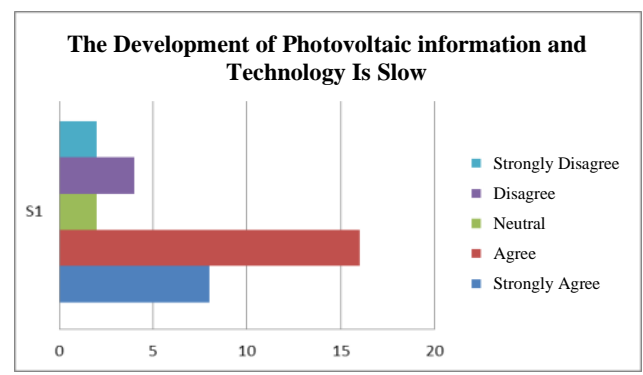

Picture 1. Photovoltaic Information and Technology Development

\subsection{Application of 3R in Photovoltaic Manufacturing}

Photovoltaic manufacturing is still in the process of development, so the National Standardization Agency has not issued SNI related to the application of $3 \mathrm{R}$ in the photovoltaic manufacturing process. Researchers at the National Renewable Energy Laboratory (NREL), United States, have conducted a final management study of photovoltaic modules. Seeing the $3 \mathrm{R}$ photovoltaic research efforts that are still in development by developed countries, Indonesia as a developing country does not yet have access to sufficient information to regulate regulatory standards related to $3 \mathrm{R}$ photovoltaics [11].

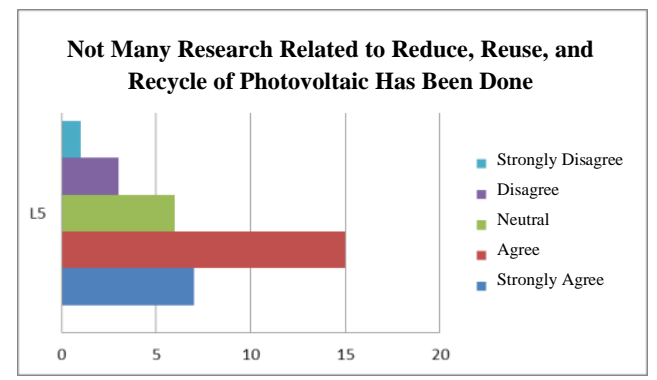

Picture 2. Application of 3R In Photovoltaic Manufacturing

\subsection{Photovoltaic Experts}

The result shows that the majority of respondents agreed that: "Indonesia lacks photovoltaic experts". The BPPT feasibility study in 2012, state that the establishment of photovoltaic industry could build new job opportunities for 35000 local citizen. The S5 questionnaire show 59\% of respondents agree that Indonesia still lacks local experts to create photovoltaic with high local content. Therefore, the government needs to prepare human resources as skilled experts ${ }^{[12]}$. This is due to two things, namely: "photovoltaic has not become a topic of lecture learning", and "the government has not collaborated much with universities/institutes to conduct photovoltaic research \& development". 


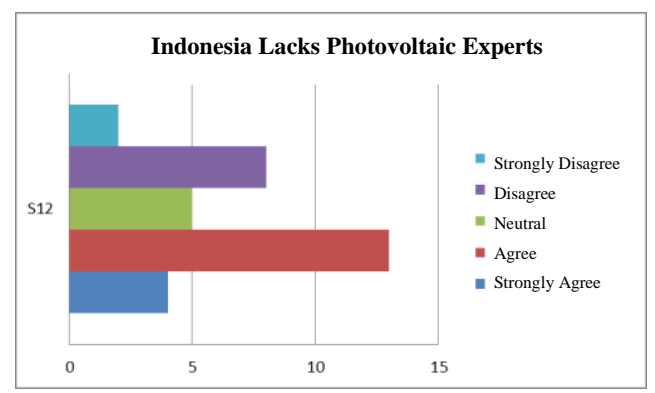

The Government Has Not Collaborated Much with Universities/Institutes to Conduct Photovoltaic Research \& Development

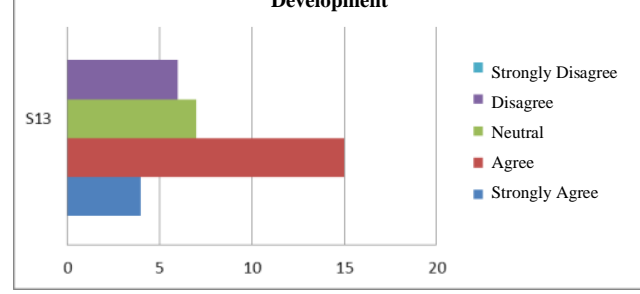

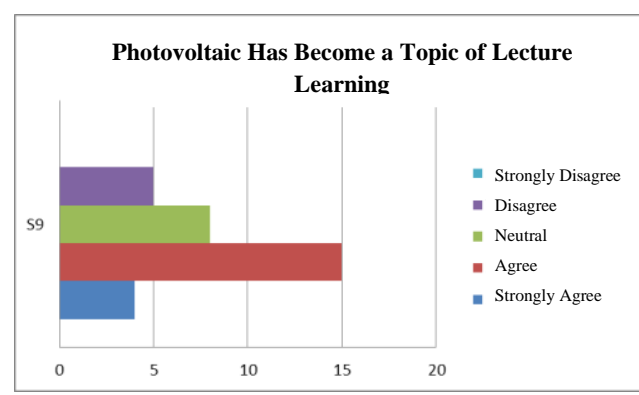

Lack of Local Experts to Develop Photovoltaic with High Local Content

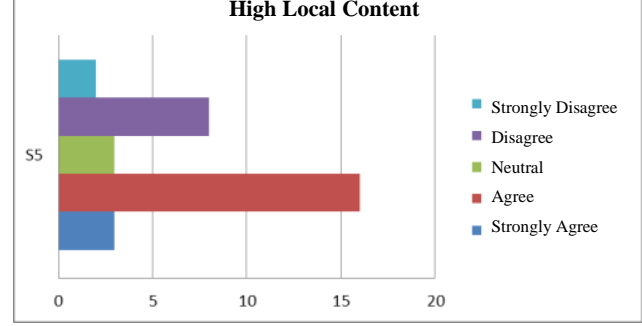

Picture 3. Photovoltaic Experts

\subsection{Rooftop Photovoltaic Procurement}
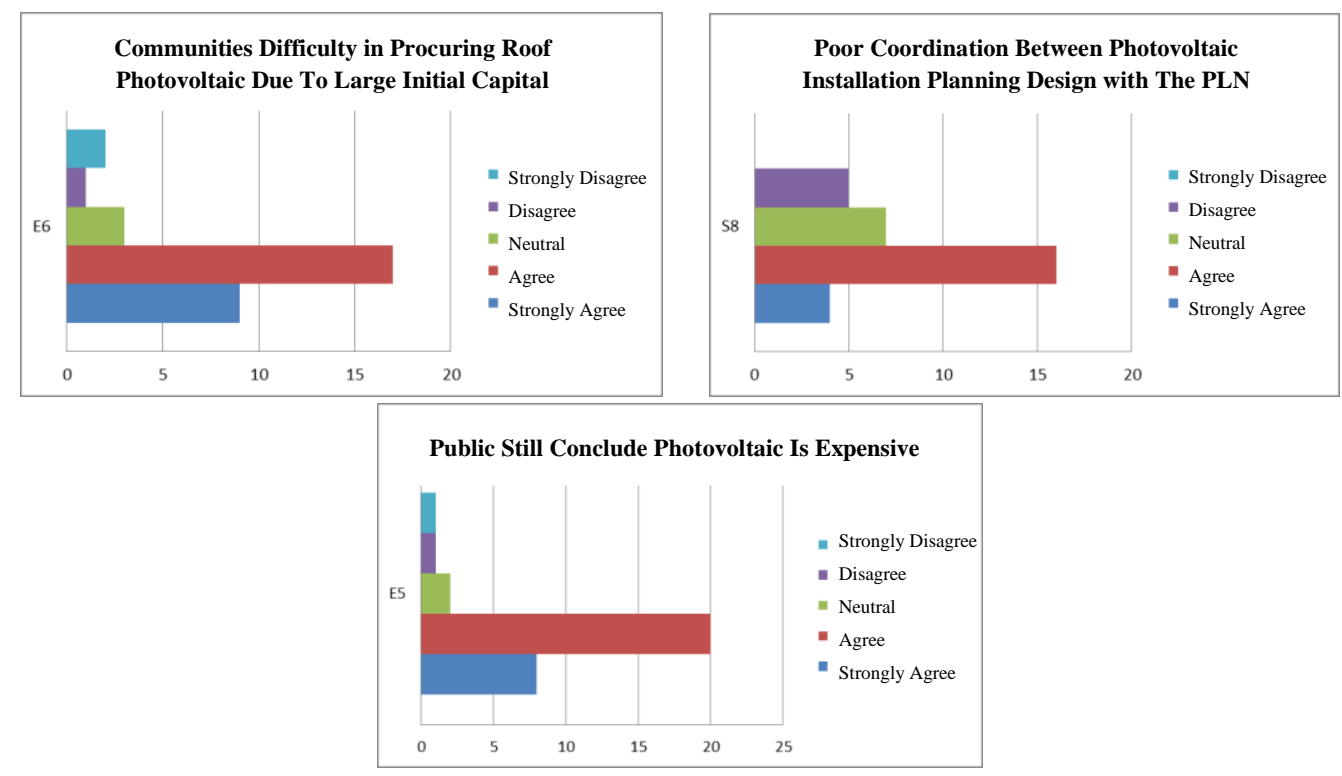

Picture 3. Rooftop Photovoltaic Procurement

One of the challenges of developing photovoltaic in Indonesia is the high cost of producing PV mini-grid [13] [14]. In 2018, there are only $17.8 \%$ of households in Indonesia that are able to procure photovoltaic and its supporting components ${ }^{[15]}$. Currently, the use of photovoltaic can only be applied to the high-end residential market because of the high construction costs and basic costs. Batteries are crucial in the implementation of off-grid electrical systems. However, the price of batteries is 3 times more expensive than solar 
panels ${ }^{[16]}{ }^{[17]}$. Hence people prefer on-grid electricity systems that rely on electricity intake from PLN's power plant instead of batteries. However, the results of the S8 code questionnaire stated that $66 \%$ of respondents agreed that the coordination of photovoltaic planning with PLN was constrained. Ministerial Regulation Number 49 of 2018 makes it difficult to install photovoltaic on a small scale (1-2 photovoltaic) because small vendors are not allowed to install photovoltaic with an on-grid electricity system. This creates obstacles for people with low financial capacity to procure photovoltaic roofs ${ }^{[18]}$.

\subsection{Expensive Domestic Photovoltaic}

Photovoltaic prices in Indonesia are more expensive than imported photovoltaics because the solar panel industry in Indonesia is generally still in the form of assembling factory. Photovoltaic factories in Indonesia that still need to import materials and machines from abroad ${ }^{[19]}$. Domestic solar panel company tends to purchase the imported material on smaller scale, thus making the purchase price more expansive ${ }^{[20]}$.
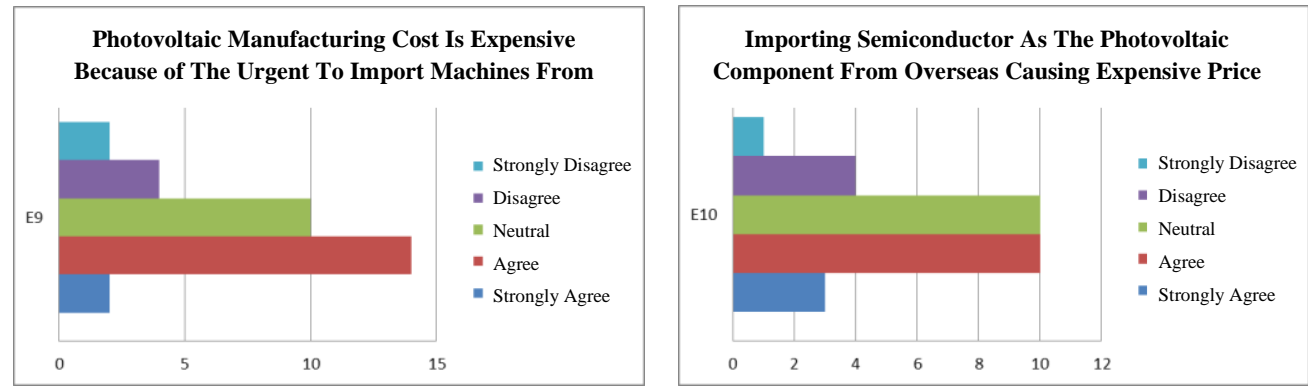

Picture 4. Expensive Domestic Photovoltaic

\subsection{The Role of Financial Institution}

IEEFA released a study related to the challenges of developing solar power in Indonesia. Policies that apply in Indonesia make it difficult for solar power enthusiasts and investors. In fact, the policy is impressed that it cannot be implemented because it makes it difficult for investors to see the financial benefits of installing a rooftop solar power system [21]. The lack of support from foreign investors causes people look for banking institutions support. Currently, only one banking institution, namely BPRS Lantabur Tebuireng in East Java, provides credit for the purchase of rooftop solar power equipment to reduce procurement expenditures in the early stages ${ }^{[22]}$.

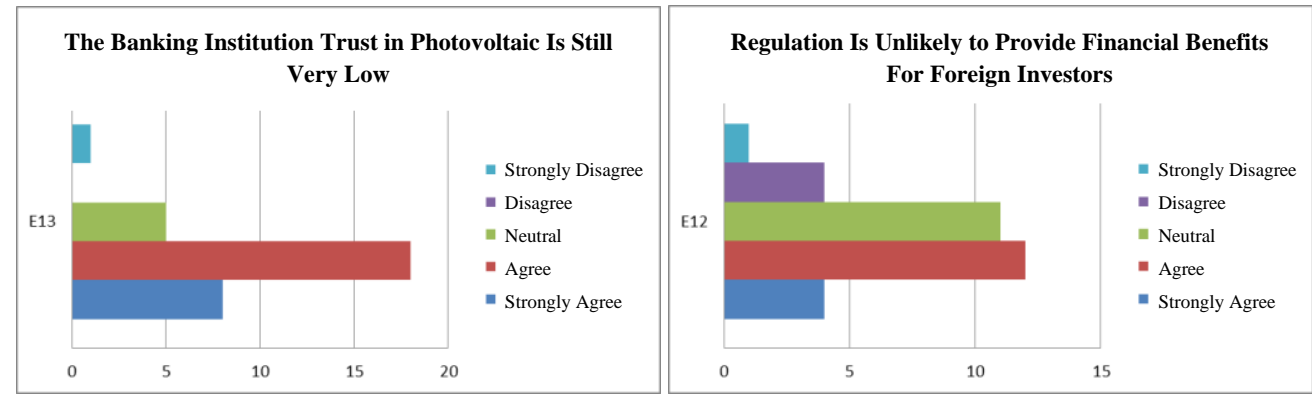

Picture 5. The Role of Financial Institution 


\subsection{Country Economic Crisis}

The global crisis caused by the COVID-19 pandemic has affected Indonesia. The development of photovoltaic roofs is experiencing a weakening economy. The price of rooftop PV mini-grid units rose by around 15\% -20\%. Based on a survey conducted by IESR on companies engaged in the PLTS Engineering, Procurement, and Construction (EPC) sector, it is said that the demand for rooftop solar PV at the household scale in March-April 2020 has contracted by 50\%-100\%. Meanwhile, the commercial and industrial segments experienced a contraction of $50 \%-70 \%{ }^{[23]}$.

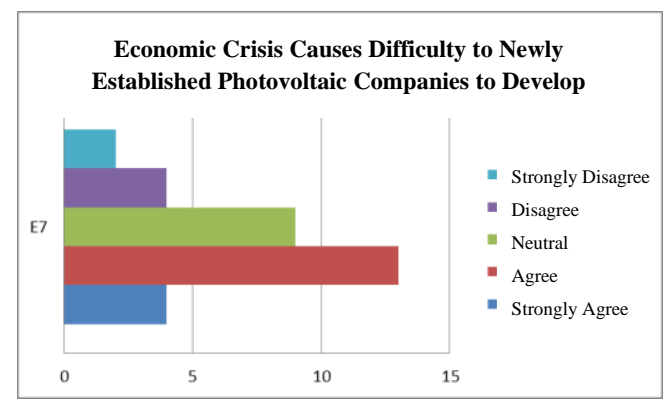

Picture 7. Country Economic Crisis

\subsection{Domestic Photovoltaic Development Agencies}

The research questionnaire shows that the majority of respondents do not agree with the statement that: "There is already an agency that is fully responsible for developing photovoltaic in Indonesia". Therefore, it is necessary to have a cooperation agreement between the government and the photovoltaic developer association. The cooperation agreement aims to give full responsibility to the association so as to strengthen the association's role in developing solar panels in Indonesia ${ }^{[24]}{ }^{[25]}$.

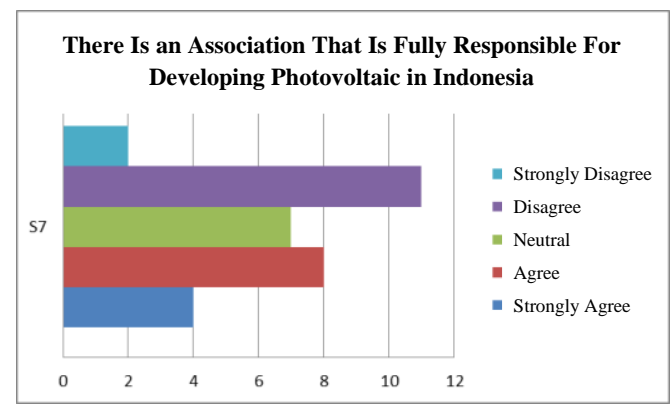

Picture 6. Domestic Photovoltaic Development Agencies

\section{CONCLUSION}

Economic and social factors have become the biggest obstacles in the development of on-site photovoltaic in Indonesia. Meanwhile, environmental barriers are more recessive. It is concluded that photovoltaic is still considered expensive by the public, this is because local photovoltaic has a higher price than imported photovoltaic. Photovoltaic companies in Indonesia tend to assemble imported materials from abroad causing higher local price. 
Therefore, it is necessary to have a local company capable of producing photovoltaic from raw materials. In order to enable this to happen, the government needs to prepare laws and regulations that are able to attract photovoltaic investors from foreign countries. Foreign investors has the role to increase the number of experts and research related to photovoltaic. To achieve the GNSSA target that supports the SDGs, the government needs to divert non-renewable energy subsidies to renewable energy such as photovoltaic because the level of trust from the financial agency in photovoltaics is low. Providing subsidies for photovoltaic purchases allows more people to implement on-site photovoltaic systems.

\section{ACKNOWLEDGMENT}

The author realizes that, without the help and guidance of various parties this research will not be completed properly. Therefore, the authors would like to thank: Leo Bambang Budi Prasetyo, S.T., M.T. as the head of the Civil Engineering study program ITSB; Annisa, S.T., M.T. and Siswanti Zuraida S. Pd., M.T. as the advisory lecturer.

\section{REFERENCE}

1) Sustainable Development Goal 7: Targets and Indicators. (n.d.). Retrieved from Sustainable Development Goals Knowledge Platform: https://sustainabledevelopment.un.org/sdg7

2) Global Alliance for Buildings and Construction, I. E. (2019). 2019 Global Status Report for Buildings and Construction : Toward energy emission, efficient, and resilient buildings construction sector.

3) Dewan Energi Nasional. (2019). Indonesia Energy Outlook 2019. Jakarta: Secretariat General of the National Energy Council.

4) Al-Ghamdi, S. G., \& Bilec, M. M. (2016). On-Site Renewable Energy and Green Buildings: A System-Level. Environmental Science \& Technology, 4606-4614.

5) IESR. (2019, April 14). Rooftop Solar dan Demokrasi Energi di Indonesia. Retrieved from IESR Website: https://iesr.or.id/surya-atap-dan-demokrasi-energi-diindonesia

6) Sun, H. Z. (2014). China's solar photovoltaic industry development: The status quo, problems, and approaches. Applied Energy, 221-230.

7) Kotak, Y. I. (2015). Impact of ground albedo on the performance of PV systems and its economic analysis. $N$ 7th International Conference on Solar Radiation and 
Daylight, 21-22.

8) Singh, K. N. (2017). Public opinion on solar photovoltaic energy utilization-A survey based study. International Conference on "Smart and Sustainable Initiatives for Energy within Environmental Constraints, , 28-34.

9) IEA. (2019). Solar Energy Mapping The Road Ahead.

10) Anonymous. (2019, Juli 30). Retrieved from

https://www.liputan6.com/bisnis/read/4025361/pengembangan-listrik-tenagasurya-ri-jauh-tertinggal-dari-vietnam

11) Anonymous. (2020, July 18). Usai Masa Pakai, Ilmuwan Pikirkan Strategi Daur Ulang Panel. (Sindonews) Retrieved 2020, from https://tekno.sindonews.com/read/105078/123/usai-masa-pakai-ilmuwanpikirkan-strategi-daur-ulang-panel-surya-1595034437? showpage=all

12) Syahni, D. (2016, November 29). Retrieved from https://www.mongabay.co.id/2016/11/29/pengembangan-listrik-tenaga-suryamasih-terkendala-mengapa/

13) Anonymous. (2018, Juli 17). Pengembangan Energi Surya Berjalan Lambat. Retrieved from Warta Ekonomi:

https://www.wartaekonomi.co.id/read187674/pengembangan-energi-suryaberjalan-lambat.html

14) Salsabila, P. (2019, September 4). Mengapa Panel Surya Masih Sulit Digunakan pada Hunian? Retrieved from Bisnis.com:

https://ekonomi.bisnis.com/read/20190904/47/1144369/mengapa-panel-suryamasih-sulit-digunakan-pada-hunian

15) IESR. (2018, Juli 3). Retrieved from https://iesr.or.id/en/kapasitas-plts-indonesiamasih-minim-3

16) Amelia, A. R. (2018, Februari 1). Arcandra Ungkap Enam Sebab PLTS Sulit Berkembang di Indonesia. Retrieved from Kata Data: https://katadata.co.id/arnold/berita/5e9a5609bfb9c/arcandra-ungkap-6penyebab-plts-sulit-berkembang-di-indonesia

17) Anonymous. (2013, Februari 22). Retrieved from https://finance.detik.com/energi/d2177424/ini-alasan-pembangkit-listrik-matahari-sulit-berkembang-di-ri 
18) Anonymous. (2018, November 27). Retrieved from

https://kumparan.com/kumparanbisnis/mau-pasang-panel-surya-di-ataprumah-izin-dulu-ke-pln-1543310096630373382/full

19) Thomas, V. F. (2019, Februari 27). Peneliti Ungkap Penyebab Panel Surya Lokal Lebih Mahal dari Impor. Retrieved from tirto.id: https://tirto.id/penelitiungkap-penyebab-panel-surya-lokal-lebih-mahal-dari-impor-dhUB

20) Hamdani, T. (2020, Juli 28). detikFinance. Retrieved from Harga Panel Surya di RI Lebih Mahal Dibanding China: https://finance.detik.com/energi/d5110980/harga-panel-surya-di-ri-lebih-mahal-dibanding-china

21) Syahni, D. (2019, Maret 17). Kajian: Regulasi Belum Ramah Pengembangan Pembangkit Surya. Retrieved from Mongabay: https://www.mongabay.co.id/2019/03/17/kajian-regulasi-belum-ramahpengembangan-pembangkit-surya/

22) Intan, G. (2018, Oktober 10). Rendah, Minat Masyarakat Indonesia Gunakan Listrik Surya Atap. Retrieved from VOA: https://www.voaindonesia.com/a/rendahminat-masyarakat-indonesia-gunakan-listrik-surya-atap/4607746.html

23) Hidayat, K. (2020, April 21). Terpapar dampak corona, pengembangan pembangkit listrik surya menjadi suram. Retrieved from Kontan.co.id: https://industri.kontan.co.id/news/terpapar-dampak-corona-pengembanganpembangkit-listrik-surya-menjadi-suram

24) Tentang GNSSA. (2019). Retrieved from Wedosolar Indonesia: https://www.wedosolarindonesia.com/tentang-gnssa/

25) Saputra, G. (2020, September 24). Tiga Tahun Gerakan Nasional Sejuta Surya Atap: Perlu Upaya Bersama untuk Mencapai Orde Gigawatt. Retrieved from IESR: https://iesr.or.id/tiga-tahun-gerakan-nasional-sejuta-surya-atap-perlu-upayabersama-untuk-mencapai-orde-gigawatt 